\title{
SPRØYTEUTDELING I FENGSLER: NOEN PRAKTISKE ERFARINGER
}

AV unIVERsitetsleKTOR DR. PHIL. KNUT PAPENDORF

This article discusses projects, especially in German prisons, where the prisoners have been given access to clean syringes. The projects have all been evaluated. In all of these projects the exchange of syringes was designed to go almost unnoticed by the prison staff. Exchanges took place in two different ways, either through automatons placed where the staff could not see them, or through dissemination by people working for the Drug Prevention Advisory Service. The evaluations show that such projects depend on the acceptance of both prison staff and politicians. They also show that exchanging syringes is quite feasible even in prison. There were no problems in connection with the actual exchanges or with prisoners possessing syringes. The risk of being infected with HIV or hepatitis was reduced, and there were no new infections during the period of evaluation. *

\section{Innledning}

Liberaliseringen av den mellomeuropeiske narkotikapolitikken fra slutten av 1980-tallet med hovedvekt på skadereduksjonstanken er knyttet til "Frankfurtresolusjonen" fra 1990. Denne helomvendingen av narkotikapolitikken i byer som nettopp Frankfurt, Hamburg, Zürich og Amsterdam resulterte som kjent i etablering av en storstilt bruk av substituering med metadon, sprøyteutdeling for å minske smittefaren, etablering av helserom/sprøyterom o. 1. (Papendorf 2002, s. 29 flg.).

Det å åpne opp for denne liberale narkotikapolitikken også for fangebefolkningen, har vist seg som vanskeligere. ${ }^{1}$ Realiteten er stadig karakterisert ved at fengselsmyndighetene synes å ha store problemer med å overholde helt basale krav til et helsemessig forsvarlig minimumsnivå i fengslene. Dette gjelder primært for en forsørgelse med rene sprøyter til fanger som er rusmiddelavhengige. Dette er svært beklagelig fordi bruk av narkotika i fengslene synes å være et tiltakende problem og med dette også smittefaren p.g.a. flerbruk av sprøytene, "drug sharing" og "work sharing". ${ }^{2}$ I fengslene er altså infeksjonsrisikoen vedrørende HIV/Aids og hepatitt A, B, og spesielt C overproporsjonalt høy sammenliknet med samfunnet ellers. ${ }^{3}$

\footnotetext{
* Title in English: Handing out Needles in Prisons: Experiences from especially Germany. Original in Norwegian.
} 
Andelen av narkotikabrukere i forskjellige europeiske lands fengsler er vanskelig å fastslo p.g.a. mangel på et felles kategorisystem for narkotika og narkotikabrukere og mangel på statistiske opplysninger om narkotikaproblemet i fengslene. Men det kan regnes med at ca. 20-50 \% av fangene er misbrukere av narkotiske stoffer i forskjellige europeiske land. Det rapporteres i denne sammenheng for kvinnelige fanger en andel av rusmiddelbrukere på inntil $70 \%$ i enkelte tyske fengsler (Stöver 2001 a, s. 135 f). På bakgrunn av disse tallene er det ikke forunderlig at det hevdes av enkelte observatører at fengslene og fangesubkulturen $\mathrm{i}$ mellomtiden er totalt dominert av narkotikakulturens verdier, adferdstyper og holdninger (O'Mahony 1997, s. 42; sitert etter Stöver ibid., s. 134).

I en nordisk kontekst har visjonen om et rusfritt samfunn ${ }^{4}$ fortsatt mange støttespillere. Den medfølgende repressive rusmiddelpolitikken med et høyt straffenivå forskyver rusmiddelproblemet $\mathrm{i}$ enda sterkere grad til fengslene. Men de nordiske fengslene er overhodet ikke innstilt på denne oppgaven. Verken Norge, Sverige, Danmark eller Finland opererer med tilbud til sine fanger med rusmiddelproblemer som går på å dele ut sprøyter for å hindre at fangene smitter seg med hepatitt virus C og HIV. Den enkle løsningen ville være å tilby det man også tilbyr narkomanene utenfor fengslene. ${ }^{5}$ Det man i stedet gjør for eksempel i Danmark og Norge, er å tilby klorin i fengslene for at fangene kan rense brukte sprøyter. Dette kan betraktes som tiltak i en smittevernstrategi hvor man har anerkjent at det finnes sprøyter i fengselet. Men det å ta skrittet helt ut og dele ut rene sprøyter, synes stadig å støte an mot det moralsk forankrete kravet om det rusfrie (fengsels-)samfunnet.

Jeg var ovenfor inne på at "Frankfurt-resolusjonens" politikk ikke ble omformulert for fengslene i de landene som er tilsluttet denne resolusjonen. Dette er ikke helt riktig. Riktig er at den liberale narkotikapolitikken som danner grunnlaget for "Frankfurt-resolusjonen" ikke generelt fikk innpass i disse landenes fengselspolitikk. Men man åpnet opp for enkelte prosjekter med sprøyteutdeling. Sprøytene ble delt ut til fanger enten ved å gi dem direkte "hånd fra hånd" eller ved å sette opp automater der fanger uten kontroll fra fengselsmyndighetene kan få rene sprøyter. Sveits startet allerede i 1992 med tilsvarende prosjekter $^{6}$, Spania (fra 1997) ${ }^{7}$ og Tyskland (fra 1996) fulgte senere. Tilbudet om bytte av sprøyter ble supplert av et forsterket tilbud om behandling (metadon, HIVhjelpeapparat).

I det følgende skal det rapporteres om en del slike tyske prosjekter som har blitt evaluert vitenskapelig.

\section{Sprøyteutdeling i delstaten Berlin}

Sprøyteutdeling i et kvinnefengsel (Justizvollzugsanstalt (JVA) Lichtenberg)

Prosjektet $^{8}$ startet i oktober 1998 med en intensiv forberedelse ved bl.a. etterutdanningsprogrammer for betjentene samt utdeling av skriftlige materiale om 
prosjektet; tilbud av ukentlige enkeltsamtale med betjentene i prosjekttiden i og utenfor fengslet (gjennomført av Berliner Aids-Hilfe). For fangene ble det ved prosjektstart også gjennomført en informasjonskveld med evalueringsforskere og HIV-hjelpen; dessuten finnes det ukentlige konsultasjonsmuligheter på fengslenes avdelinger. Bytting av sprøyter er et tilbud for alle kvinnelige fanger som befinner seg på en avdeling for rusmiddelbrukere.

\section{Utdelingen av sprøytene}

Nye fanger finner i sin celle skriftlig informasjonsmateriale om prosjektet samt en sprøyteattrap - en såkalt "dummy". Med denne liksomsprøyten kan fangene ta ut sprøyter, askorbinsyre og bomullsdotter av en automat. Automaten er en modell fra Sveits. Automatene blir fylt og kontrollert flere ganger i uken av håndverkere beskjeftiget i fengslet. Det er lagret en automat til i kjelleren som reserve. Tre andre befinner seg på avdelingene. Automatene er slik lokalisert på avdelingene at kvinnene som tar en sprøyte ut av automaten, ikke kan sees fra tilfeldig forbipasserende betjenter. Automaten er tilgjengelig på avdelingene fra $\mathrm{kl} 6.00$ til kl 21.30. Pr. person er det tillatt å ha én sprøyte. Hvis en fange har flere, ble den fratatt henne. Sprøyten må ligge på en bestemt plass i cellen. Det som er ivaretatt med denne utdelingsprosedyren, er at det ikke kan kontrolleres av fengselspersonalet hvor mange sprøyter fangene bytter og med dette heller ikke fangenes eventuelle bruk av rusmiddel.

\section{Sprøyteutdeling i et mannsfengsel (JVA Plötzensee)}

Dette prosjektet startet litt senere, i februar 1999. I forskjell til kvinnefengslet opereres det i dette fengslet ikke med sprøyteautomater. Fangene får her ved å levere sin liksomsprøyte en sprøyte samt askorbinsyre og bomullsdotter i "helserommet". Bytting av sprøytene blir gjennomført av medarbeidere i Berlins Aids-hjelpen. Det er tre ganger i uken konsultasjonstid på 11/2 time. "Helserommet" er slik lokalisert at det ikke gir innsyn for betjentene.

\section{Evaluering}

Evaluering ble fra prosjektets oppstart gjennomført av Institut für Tropenmedi$z_{i n .}{ }^{9}$ Rusmiddelbrukerne ble intervjuet om "rusmiddelkarrieren", konsummønsteret og risikoadferden, hver tredje måned. Dessuten fulgte en undersøkelse på antistoff mot bl.a. HIV. Betjentene ble intervjuet i startfasen av prosjektet og etter ett år. Spørsmålene gjaldt betjentenes holdninger, erfaringer og engstelser. I kvinnefengselet ble det i 1999 utgitt 900 sprøyter og tilbehør. Statistikken og utsagn av kvinnene i intervjuene tydeliggjør at ikke tilgjengeligheten av sprøytene, men tilgjengeligheten av narkotika er den dominerende faktoren for det injiserende rusmiddelbrukets intensitet.

Den praktiske håndteringen av utdelingen av sprøytene synes etter en første tilvenningsfase å være uproblematisk, og er integrert i hverdagen på avdelingene. 
Noen betjente sier til og med at deres engstelser vedrørende en massiv økning av sprøyteinjeksjoner, disiplinproblemer og trussel mot betjente med brukte sprøyter ikke ble bekreftet. Disse utsagn ble også bekreftet ved evalueringen, som har vist at sprøyteutdelingen er praktisk gjennomførbar og ikke byr pà sikkerhetsproblemer.

I undersøkelsen i starten av prosjektet hadde $16 \%$ av fangene HIV, $52 \%$ hepatitt B og $85 \%$ hepatitt $\mathrm{C}$. Disse resultatene ligger innenfor rammene av det man kjenner fra andre nasjonale og internasjonale studier. Det som er interessant $\mathrm{i}$ denne sammenheng, er at det i prosjekttiden med en observasjonstid på $\mathrm{i}$ gjennomsnitt ni måneder ikke forekom nyinfeksjoner.

$2 / 3$ del av de spurte betjenter var generelt positive til utdeling av sprøyte. Men $i$ forhold til eget fengsel var man mer negativt innstilt. Grunnen til den generelle positive innstillingen var hindringen av nyinfeksjoner. Den negative holdning vedrørende eget fengsel ble begrunnet med motsigelsen mellom kravet om det rusfrie fengselet og sprøyteutdelingen.

\section{Sprøyteutdeling i delstaten Hamburg}

Sprøyteutdeling ble praktisert i tre fengsler siden 1996 (JVA Am Hasenberge, Frauenteilanstalt der Jugend- und Frauenvollzugsanstalt Hahnöfersand). ${ }^{10} \mathrm{I}$ disse fengslene ble sprøytene utdelt "pr. hånd" ved fengslenes "medisinske tjeneste". I et åpent fengsel (JVA Vierlande) skjer utdelingen ved automat og av personer ved den eksterne rusmiddelomsorgen.

Også i fengselsvesenet i Hamburg er det sentrale målet å minske rusmiddeltilgangen, og å støtte fangene slik at de kan leve uten narkotika. Med fanger som ikke kan nås med slike strategier, står i et neste skritt skadereduksjonstanken i forgrunnen med bl.a. utdeling av sprøyter.

\section{Sprøyteutdeling i JVA Vierlande}

I gjennomsnitt $\mathrm{i}$ undersøkelsestiden satt 265 fanger i dette fengselet. Siden det handler om et åpent fengsel, var den gjennomsnittlige oppholdstiden med fire måneder lavt. Dette ble spesielt av personer som var for modellprosjektet kritisert fordi man mente at de fleste fanger hadde permisjon og hadde for så vidt muligheten til å bytte sprøyter. Mot det ble det argumentert at det likevel kom til needle-sharing.

\section{Utdelingen av sprøytene}

Konseptet for utdelingen av sprøytene ble utviklet av en tverrfaglig sammensatt arbeidsgruppe. Man var spesiell opptatt av å ivareta anonymiteten i utdelingssituasjon. Sprøyteautomatene (seks) skulle ikke kunne overvåkes av fengselsbetjentene, og skulle kunne nås av fangene på en diskret måte.

Også her startet opplegget med utgivelsen av en dummy-sprøyte som ble utdelt av den fengselseksterne rusmiddelomsorgen. Bare én sprøyte var tillatt, 
som måtte oppbevares i en spesiell beholder i et skap i cellen p.g.a. frykt for stikkbeskadigelse. For langvarige injiserende rusmiddelbrukere med dårlige vener ble det i en automat tilbudt sprøyter med lengre kanyler. Også her ble fengselsbetjentene i informasjonsmøter forberedt og kurset av medarbeidere $\mathrm{i}$ den eksterne rusmiddelomsorgen.

I den første fasen av prosjektet ble automatene brukt hyppig av fangene. Dette skjedde nok ikke bare p.g.a. bruk av rusmiddel, men også for å teste automatene eller for å villrede vedrørende det virkelige antall av byttete sprøyter. Senere pendlet byttefrekvensen seg inn på ca. 200 sprøyter i måneden i gjennomsnitt. ${ }^{11}$

Fra juni 2000 ble utdelingsmønstret av sprøytene endret: utdeling av sprøytene skjedde nå også gjennom eksterne fra "hånd til hånd" i tidsrommet fra mandag til fredag. Dessuten kunne fangene videre benytte automatene, men antallet var redusert til to. Grunnen til denne forandringen var at man ville benytte den personlige kontakten med fangene i byttesituasjonen til å informere om infeksjonsrisikoen og etablere en videregående rusmiddelomsorg.

\section{Evalueringen}

Før oppstarten av prosjektet var $47 \%$ av fangene rusmiddelavhengige, $41 \%$ injiserte. De tilsvarende tallene sank i prosjekttiden til henholdsvis $39 \%$ og 30 $\%$. Ved rusmiddelbrukere som injiserte stadig eller delvis, var andelen på hepatitt B eller C henholdsvis $64 \%$ og $89 \%$. Det ble ingen hepatitt- eller HIV-nyinfeksjon i prosjekttiden. Resultatene i evalueringen vedrørende needle-sharing var ikke entydige. Den medisinske evaluering (Heinemann/Püschel) viste en tydelig tilbakegang av bytting av sprøytene; den sosialvitenskapelige (Gross) en viss fortsettelse med sprøyte-deling. Fangene begrunnet dette med at automatene delvis ikke fungerte som planlagt.

I evalueringstiden på 4 1/2 år ble det byttet alt $i$ alt 17.408 sprøyter. Ikke en eneste gang ble sprøytene benyttet som våpen mot medfanger eller betjenter.

\section{JVA Am Hasenberge ${ }^{12}$}

JVA Am Hasenberge er et lukket fengsel med 450 plasser. Ca. $20 \%$ av fangene bruker hard narkotika under soningen, $2 / 3$ del av dem stadig eller delvis intravenøst. $80 \%$ av denne gruppen rapporterer om utstrakt bruk av needle-sharing. På den andre siden hadde man opplysninger om at det ble pauser i bruken av narkotika under soningen i lukket fengsel eller at man fant frem til bruksformer med mindre risiko. Med dette som bakgrunn ble det søkt etter en setting for sprøytebyttingen som for det første minsket infeksjonsrisikoen tross et fortsatt risikabelt bruksmønster. For det andre skulle "hvilerommet" i det lukkete fengsel ikke motarbeides ved en for lett tilgjengelighet av rene sprøyter. Forberedelsesgruppen valgte på bakgrunn av disse overveielser ikke å satse på automatløsningen, men på en bytteløsning "fra hånd til hånd". Sprøytene ble byttet av fengselets egne interne helsetjeneste fra mandag til fredag i konsultasjonstiden 
på formiddagen og fra 16-17 på ettermiddagen. Hvis nødvendig kunne det også byttes sprøyter i helgene. Spesielle forhold i byttesituasjonen ble dokumentert av helsetjenesten. Fanger som bryter reglene flere ganger i sammenheng med bytting av sprøytene, kan utelukkes fra den videre deltakelse i programmet.

\section{Evaluering og sammenfatning}

I prosjektets første elleve måneder deltok 27 fanger. Elleve fanger sluttet fordi de ble tatt opp i fengselets metadonprogram. Det forekom ikke noen spesielle hendelser i sammenheng med utdeling av sprøytene. Deltakelsesgraden lå en del under forventningene. Dette henger muligens sammen med den valgte bytteløsning "fra hånd til hånd" som for en del av fangene med rusmiddelproblemer hadde for mange elementer av et høyterskeltilbud slik at de ikke kunne nås på denne måten.

For fengselsbetjentene i de tre nevnte fengsler er bytting av sprøytene blitt vanlig. Engstelse for at programmet kunne få negative følger, ble ikke bekreftet. Men likevel er mange av fengselsvesenets medarbeidere stadig skeptiske. Dette henger muligens sammen med at sprøytebyttetiltaket i Hamburg var et "topdown" tiltak, altså ønsket fra det (politiske) miljøet rundt fengselet. For å forankre programmet sterkere, er det viktig å integrere fengselsbetjentene fra begynnelsen av i prosjektplanlegging og få til løsninger som er tilrettelagt for situasjonen i fengslet. Transparens og samarbeid mellom alle deltakere er en grunnleggende forutsetning for å heve aksepten av et slikt prosjekt.

\section{Spøyteutdeling i Niedersachsen ${ }^{13}$ JVA Lingen ${ }^{14}$}

Sprøyteutdelingsprosjektet kom i dette fengslet i gang i midten av 1996 opprinnelig som toårig modellprosjekt - etter intense diskusjoner blant samtlige deltakere i modellen. Dette innbefattet fengselets lege, sikkerhetsinspektør og den fengselsinterne rusmiddelomsorgen som ble oppfordret til å komme uavhengig av hverandre med sine sakkyndige uttalelser. Etter at disse hadde uttalt seg positivt, ble det foretatt informasjonsmøter for fengselsbetjentene og fangene med fagfolk om et vidt spekter av smittevernrelaterte temaer. I disse diskusjonene ble det dessuten flere ganger trukket inn eksterne personer fra bl.a. politikken, rusmiddelomsorgen, domstolene, helserådet og den lokale Aidshjelpen. Etter at de politiske myndigheter hadde avgjort at modellprosjektet skulle bli til, ble det oppnevnt en arbeidsgruppe som skulle utvikle modellen. Arbeidsgruppens deltakere var rekruttert fra fengselet selv med inspektør, sikkerhetsleder, helsetjenesten, den lokale eksterne rusmiddelomsorgen og Aidshjelpen i Niedersachsen. ${ }^{15}$ Fengselsbetjentene ble regelmessig informert om arbeidsgruppens diskusjoner på tjenestemøter. Det som kan konstateres på bakgrunn av forarbeidet, er at prosjektet og dens gjennomføring var vel forankret blant fengselets medarbeidere og fanger. 
Utdelingen av sprøytene

I prosjektet kan bare fanger som injiserer delta. Fanger som deltar i et substitueringsprogram får ikke deltar. Grunnen for dette er at behandlingsavtalen impliserer en forpliktelse til å gi avkall på bikonsum av andre narkotiske stoffer. Selve byttingen av sprøytene skjer i lokalene til den eksterne rusmiddelomsorgen i fengselet, som kan nås av fangene uten at betjentene kan se dem. Sprøyteutdeling skjer i en setting av et lavterskel rådgivningstilbud. Etter at modellens prøvefase i juli 1998 var avsluttet, ble fanger som hadde byttet sprøyter ikke mer notert med navn i dokumentasjonsøyemed.

\section{Erfaringer}

Modellen med bytting av sprøytene medførte ikke problemer i oppstartfasen. Som deltaker i prosjektet meldte seg i første måneden alt i alt 20 fanger som i de tidligere diskusjoner hadde vist interesse for modellprosjektet. Over hele rapporttiden (inntil 30.10.2000) er det i sammenheng med sprøytebytting ikke blitt problemer. For innkjøp av sprøyter, askorbinsyre og bomullsdotter behøves ca. NOK 2500 pr. år for samtlige deltakere i programmet. I tidsrommet fra 15.7.1996 - 31.8.2001 ble det byttet ca. 9200 sprøyter av alt i alt 233 fanger.

\section{Oppsummering og situasjon i dag}

Prosjektene i Berlin og Niedersachsen er stadig i drift. I Niedersachsen er det også tilbudt andre fengsler å følge eksemplet til de nevnte fengsler, uten at det synes å være interesse for dette. I Hamburg har prosjektene måtte slutte p.g.a. en endret politisk konstellasjon med overgang fra sosialdemokratisk/grønn regjering til en konservativ/høyrepopulistisk dominert regjering.

Hva kan trekkes som generelle erfaringer ut av disse prosjektenes evaluering?

- Erfaringer viser for det første at realisering av slike prosjekter bør plasseres i en sammenheng hvor de politiske omgivelser og fengslet selv er åpent for kriminalpolitiske innovasjoner. ${ }^{16}$

- For det andre viser evalueringen av de forskjellige prosjektene at modellprosjekter med bytting av sprøyter i en fengselskontekst er praktisk gjennomførbare.

- For det tredje er det kanskje for noen en overraskelse at det ikke kom til overgrep eller problemer i byttesituasjonen og i sammenheng med besittelse av sprøyter.

- For det fjerde viser evalueringen at infeksjonsrisikoen vedrørende HIV og hepatitt kan minimeres ved et slikt tiltak og at det ikke ble nyinfeksjoner i evalueringstiden. 
- For det femte og avslutningsvis kan det konstateres at det ikke er tilgjengeligheten av sprøytene, men tilgjengeligheten av narkotiske stoffer i fengslene som er den dominerende faktor for den injiserende rusmiddelbruks intensitet.

\begin{abstract}
Alt i alt kan det med dette konstateres at de engstelser og argumenter i Norden mot modeller med sprøytebytting i fengslene som helsetiltak ikke synes å ha noe realistisk grunnlag.
\end{abstract}

\footnotetext{
Noter

${ }^{1)}$ Riktignok finnes det som et unntak et prosjekt i fengselet Oberschöngrün i Sveits hvor det fra 1995 ble delt ut "gratis" heroin til 16 fanger (Kaufmann, Dobler-Mikola, Uchtenhagen 2001, s. 127 flg.).

2) Drug sharing: hele rasjonen på sprøyten ble delt opp mellom flere brukere. Work sharing: felles bruk av brukerutstyr som filter, skje og annet (Stöver 2001 a, s. 139).

${ }^{3)}$ Men det skal også sies at ikke alle nyinfeksjoner med hepatitt eller HIV kan tilbakeføres umiddelbart til injiserende narkotikabruk. Nyinfeksjoner er også mulig på grunn av tatovering, piercing eller ikke-beskyttet seksualkontakt (Stöver 2001 b, s. 49).

4) Her ligger vel også hovedgrunnen for at skadereduksjonsdebatten aldri kom skikkelig i gang $\mathrm{i}$ Norden. Dette gjelder spesielt for Norges, Sveriges og Islands vedkommende, i mindre grad for Danmark og Finland, der visjonen om det rusfrie samfunn står mindre sterkt.

${ }^{5)}$ Warberg viser for Norges vedkommende til smittevernlovens $\S 6-1$ som hjemmel for smitteutsatte fanger til å kunne kreve tilgang til rene sprøyter (Warberg 1997, s. 82).

${ }^{6)}$ Oberschöngrün i Solothurn, Hindelbank i Bern, Champ Dollon i Genf, Realta/Cazis i Graubünden, Witzwil i Bern, Thorberg i Bern og Saxerriet i Salez.

${ }^{7)}$ Centro Penitenciario de Basauri i Vizcaya, Pamplona, Tenerife, Bilbao og San Sebastian.

${ }^{8)}$ Jeg baserer meg her på Lang og Stark 2001, s. 52 flg.

9) Avslutningsrapport: Stark/Herrmann/Ehrhardt/Bienzle, Berlin 2001

${ }^{10)} \mathrm{Jeg}$ baserer meg her på Støver 2001 b, s. 41 flg. Den vitenskapelige evaluering av prosjektene ble gjennomført av Institut für Rechtsmedizin ved Universitätskrankenhaus Epppendorf (Hamburg) (Heinemann/Püschel 1998) og ved Kriminologisches Forschungsinstitut Niedersachsen (Heinemann/Gross 2001).

11) I gjennomsnitt i måneden i 2000204 sprøyter (Stöver 2001 b, s. 43).

${ }^{12)}$ Utdelingen av sprøytene i Frauenvollzugsteilanstalt Hahnöfersand fulgte stort sett samme mønsteret. Derfor rapporteres det ikke spesielt om denne modellen.

${ }^{13)}$ Det bygges her på Lettau, Sawallisch, Schulten og Tieding 2001, s. 35 flg.

${ }^{14)}$ Det finnes et prosjekt til i Niedersachsen i JVA Vechta som her ikke skal rapporteres om fordi forskningsprofilen er lik den i JVA Lingen.

${ }^{15)}$ Arbeidet med konseptutviklingen inkluderte besøk av et fengsel i Sveits (Schöngrün/Solothurn) på en uke som på denne tiden allerede praktiserte sprøyteutdelingen.

${ }^{16)}$ Dette synes i dag enda mer riktig enn da jeg leverte denne artikkelen til redaksjonen. Det politiske regimeskiftet i delstaten Niedersachen til ny regjering dominert av CDU og FDP har medført det beklagelige resultatet at prosjektene med sprøyteutdeling i Niedersachsens fengseler er innstilt med dato 1. juni 2003. Dette skjer mot de involverte fengslenes uttrykkelige vilje.
} 


\section{Litteratur}

Gross, U.: Wissenschaftliche Begleitung und Beurteilung des Spritzentauschprogramms im Rahmen eines Modellversuchs der Justizbehörde der Freien und Hansestadt Hamburg, Hannover: Kriminologisches Forschungsinstitut Niedersachsen e.V. 1998 (Forschungsbericht nr. 73)

Heinemann, A./ Püschel, K.: Prävalenz und Transmission von viralen Infektionskrankheiten im geschlossenen Strafvollzug in Hamburg-Fuhlsbüttel (Anstalt II und V). Hamburg: Institut für Rechtsmedizin 1998

Heinemann, A./ Püschel, K.: Pilotprojekt zur Infektionsprophylaxe für Drogenabhängige in der Anstalt des offenen Vollzugs in Vierlande (Anstalt XII) - Medizinische Begleitforschung, Hamburg: Institut für Rechtsmedizin 1998

Kaufmann, Beat/ Dobler-Mikola, Anja/ Uchtenhagen, Ambros: Kontrollierte Opiatabgabe im Schweizerischen Strafvollzug, i: Jacob, Keppler og Stöver (utg.) LebHaft: Gesundheitsförderung für Drogen Gebrauchende im Strafvollzug, Aids-Forum Dah, bind 42/1, Berlin 2001, s. 127 flg.

Lang, Fredi/Stark, Klaus: Die Berliner Modellprojekte zur Spritzenvergabe in Haft, i: Jacob, Keppler og Stöver (utg.) LebHaft: Gesundheitsförderung für Drogen Gebrauchende im Strafvollzug, Aids-Forum Dah, bind 42/2, Berlin 2001, s. 52 flg.

Lettau, Sabine/ Sawallisch, Peter/ Schulten, Inge/ Tieding, Klaus: Das Spritzenumtauschprogramm der Justizvollzugsanstalt Lingen, i: Jacob, Keppler og Stöver (utg.) LebHaft: Gesundheitsförderung für Drogen Gebrauchende im Strafvollzug, Aids-Forum Dah, bind 42/2, Berlin 2001 b, s. 35 flg.

O'Mahony, P.: The Drugs Culture and Drug Rehabilitation within the Prison System, i: The management of Drug Offender in Prison and on Probation. Seminar Paper, IMPACT, Department of Justice

Papendort, Knut: Norsk narkotikapolitikk og lærdommen fra kontinentet, i: Kromnytt nr. 1/2002, s. $29 \mathrm{flg}$.

Stark, K./Herrmann, U. / Ehrhardt, S./ Bienzle, U.: Modellprojekt Spritzenvergabe im Berliner Justizvollzug. Abschlussbericht der Begleitforschung. Berlin 2001

Stöver, Heino: Hilfen für drogenabhängige Gefangene in den Gefängnissen Europas, i: Jacob, Keppler og Stöver (utg.) LebHaft: Gesundheitsförderung für Drogen Gebrauchende im Strafvollzug, Aids-Forum Dah, bind 42/1, Berlin 2001 a, s. 133 flg.

Stöver, Heino: Spritzenumtauschprogramme in drei Hamburger Justizvollzugsanstalten, i: Jacob, Keppler og Stöver (utg.) LebHaft: Gesundheitsförderung für Drogen Gebrauchende im Strafvollzug, Aids-Forum Dah, bind 42/2, Berlin 2001 b, s. 41 flg.

Warberg, Lasse: Rene sprøyter for fanger - narkotikabekjempelse eller smittevern, i: LoR 1997 , s. 81 flg.

\section{Adresse: Institutt for kriminologi og rettssosiologi, avd. for kriminologi St. Olavs plass 5 PB 6706 St. Olavs plass 0130 Oslo}

